\title{
The Future of Refugee and Displaced People: A Post Covid-19 Perspective
}

\author{
A N M Zakir Hossain ${ }^{1,2}$ \\ ${ }^{1}$ Faculty of Public Governance and International Studies, National University of Public Service, Budapest, \\ Hungary \\ ${ }^{2}$ Department of Agricultural Economics, Bangladesh Agricultural University, Mymensingh, Bangladesh \\ Correspondence: A N M Zakir Hossain, Ph.D. Research Fellow, Faculty of Public Governance and International \\ Studies, National University of Public Service, Budapest, Hungary. Tel: 367-0381-8941. E-mail: \\ anmzakirhossain@bau.edu.bd
}

Received: November 18, 2020

Accepted: December 18, 2020

Online Published: December 30, 2020

doi:10.5539/ass.v17n1p21

URL: https://doi.org/10.5539/ass.v17n1p21

\begin{abstract}
The article observes the current changes of the refugee crisis after the effect of COVID 19 that can lead to a growing crisis of more than 79.5 million refugee and displaced people across the world. The study aims to examine the prevailing and forthcoming challenges of refugees and displaced people. A systematic review was followed to conduct the study and articles were selected based on their inclusion criteria. There is a growing need to understand the refugee crisis coupled with the necessity to design practical resolutions. The study found institutional and financial support are the main drivers for the refugee management in their distress voyage. These are challenged due to the adverse effect of the COVID 19 epidemic and the current downturn of the world economy. The study tries to stress the array of institutions that are working on the support for the refugees and displaced people that are challenging and can result in a crisis in the future. The paper concludes with an argument about the changing scenario of policies for migration which are restricting and changing due to the existing pandemic which demands synergistic performance within the government to manage the crisis.
\end{abstract}

Keywords: refugee, COVID-19, displaced people, crisis

\section{Introduction}

The world witnessed a very unprecedented time that never experienced. The contemporary global debate on refugee and displaced people and its multi-pronged impact have had a strong echo in the academic and political discussions in the contemporary world. According to the current report of the United Nations High Commissioner for Refugee (UNHCR), the amount of forcibly displaced persons is 79.5 million, where is 26 million refugees, 45.7 internally displaced people, 4.2 asylum seekers as a result of persecution, conflict, violence, or human rights violations at end-2019. Among them, only 25.9 million refugees under UNHCR's mandate, where 80 percent of the refugees are hosted by their neighboring country of origin, and over half of them are under the age of 18 (UNHCR, 2020a). The outbreak COVID-19 can influence the refugee crisis management in the coming days all over the world due to their socio-economic, health, and other vulnerabilities. The epidemics gradually amplified in spread, rate, and ferocity with a noticeable rise after March 2020 because of human mobility, transport, and the population of the cities steadily grew. Contemporary accounts, patterns of spreads, and mortality all confirmed COVID-19 as a health hazard for human civilization and is challenging and threatening to the way of life where the refugees and displaced are meager due to their present socio-economic and political condition that needs attention straightway (Bhopal, 2020). Refugees and displaced people live in congested camps without an adequate economic facility and minimum standard space for a person (UNHCR, 2020a) though epidemics do not affect all people equally, rather the poor are more vulnerable to it (Duncan, 2005). As refugees are living in a very overcrowded environment, social distancing might not be practical for them (Orcutt et al., 2020). COVID-19 can easily spread among them (Albon, Soper, \& Haro, 2020) however, social distancing vital for a stay away from the infection of the virus (Mubarak, 2020) because some of these populations have health complications with any contagion because of primary chronic conditions. But the limited existence or nonexistence of COVID-19 infection in refugee camps also generating an extra burden and can increase the health and social inequalities (Mesa Vieira et al., 2020) on the current health-care system due to their 
public health and socio-economic conditions.

COVID 19 pandemics is playing a critical role in redesigning the governance architecture and expedite to the gap of understanding the crisis in recent times to promote human development and to protect lives (Manderson and Levine, 2020). As a result, the governance and management of pandemics in refugee camps are crucial for public health and national security (Everard et al., 2020) for developing and developed countries (Shaw, Kim, and Hua 2020). In addition, COVID-19 pandemics added as a new phenomenon for almost all the branches of basic and social sciences and reveals several unparalleled challenges for public health (Bhopal, 2020; Savin \& Guidry-Grimes, 2020), governance, economy, and society (Martinez-Juarez et al., 2020) while it will be perilous if they become forgotten after this pandemic. The refugees and displaced people across the world supplemented the contemporary human movement which is remodeling the traditional migration (Zapata, 2019). It is uncertain how the countries will start to receive the immigrants from the refugee and displaced people after the COVID-19 epidemics. However, 'it is evident that access to the international protection regime has also become more and more restrictive in recent years, with Western states erecting ever greater physical and bureaucratic barriers ' (Haddad, 2001).

Trends in human movement mostly depend not only on human actions, changes of productions, consumption, and conservation but also policy diffusions 'that policies in one unit (country, state, city, etc.) are influenced by the policies of other units' (Gilardi \& Wasserfallen, 2019). As a result, since 1975 the countries that traditionally receive refugees have made major changes in their refugee resettlement programs and policies (Stein, 1983; Goot \& Watsoon, 2011) that is obvious and will continue after this COVID-19 pandemic due to the economy and the security of their country. Surprisingly refugee's distress journey did not get the exact spotlight without a few recent remarkable exemptions in 'refugee and forced migration studies' (Crawley et al., 2016). However, the research on their voyages 'remains fragmented, unsystematic, and lacking in analytical focus' (Benezer \& Zetter, 2014) while their memories remain etched with 'extreme uncertain expeditions' (Gillespie et al., 2018).

The present study focused on the issues that are challenged and will remain challenging for the refugee and displaced people in the post covid-19 era for financial and other administrative supports which are essential for their survival. So it is necessary for those who are engaged in managing the trajectory of refugee and displaced people and the COIVID-19 epidemics on regional and global policy, planning for public health management and investigating the roots and consequences needs immediate attention 'to the needs of ethnic, racial, indigenous and migrant minority groups' (Bhopal, 2020) including the large number of refugees and IDPs. The existing predicament not only forced us to accept the tragedies but also offers opportunities for policy makers and researchers to investigate innovation and adaptation for future crisis management.

\section{Methodology}

The study was intended to cover the range and scope to explain the refugee, displaced people, and Covid-19 nexus. It also strived to scrutinize the available literature on refugee features and their crises in the light of Covid-19. This research article is primarily based on the secondary sources of data on refugee and displaced people and the effect Covid-19 on their livelihoods. Refugee and displaced people are more vulnerable to Covid-19 as they have a number of inability to any crisis or disaster. The covid-19 pandemic emerged as a threat to mankind and produced several challenges where refugee and displaced people are more exposed due to their current socio-economic and political situation in the local and global political arena. The study followed a systematic approach (Jesson, Matheson, \& Lacey, 2011) to collect data by searching relevant literature from Google Scholar, Research Gate, JSTOR, PubMed, Web of Science to categorize the articles. To discover the crisis of refugee and displaced people in the Covid-19 era, the related keywords, i.e. 'Refugee', 'Displaced People', 'Refugee and Displaced people', 'Covid-19', 'Covid-19, Refugee, and Displaced People', 'Refugee Health and Covid-19', 'Food Security and Covid-19' were used to search the prevailing literature for the research. All reference lists of the identified articles, reports, and documents of a refugee context were selected. I considered research articles based on both the primary and secondary sources of data and also the non-academic published documents (i.e. report, fact sheet, etc) which were published in English. Finally extracted all relevant data from selected literature to finalize the research findings. All important human crises of the contemporary world- refuge and displaced people, humanitarian funding, food security and livelihoods, public health in the recent COVID-19 pandemic were discussed.

\section{Results}

\subsection{How Global Crisis Stimulus to Refugees and Displaced People}

Refugee itself an "occidental construction" referred to the persons who were failed to get protection from their country and forced to cross the border. Nation-state defines international migratory politics while transnational 
mobility is the exception (Nussbaum, 2007). While Johns (2004) claims migration as a problem from international law and lawyers' point of view that needs rational modification. As a result, migration is pathologized and imperative to characterize the state for the cure because "the refugee's plight is accounted for as a temporary failure of compulsory nationhood to complete itself" (Johns, 2004).

Refugees nowadays become central to the field of studies from a different school of social, legal, and biological sciences because of the size, magnitudes, and numbers. It is also evident that they reflect the conflict, violence, and unevenness of the contemporary world order. That is why the crises will remain understudy in the coming years of the twenty-first century in political philosophy, cultural geography, law, sociology, anthropology, history, psychology, public health, and epidemiology (Murray \& Skull, 2005; Kay, Jackson, \& Nicholson, 2010; Gallien, 2018a; Stone, 2018). Arts and literature on refugee explore methods of knowing and examine central questions about their experience articulation and magnetism of representing them. After the Second World War, the "U.N members had considered the refugee problem as an immediate post-war problem and assumed it could be solved in a limited time" (Halborn, 1975) where the result is palpable around the world. The postcolonial philosophy asserts precisely the unique platform to study refugee because of its intersections between social sciences and humanities to study refugee literature and arts (Gallien, 2018a). The end of the twentieth century started with major geopolitical events that triggered destructive and long-term consequences on the populace in Asia, Africa, and the Middle East. War in Afghanistan, Iraq, expansion of ISIS insurgency, Arab revolution, and war in Syria with the fall of the Gaddafi government in 2011 in Libya (Gallien, 2018a) has turned these places hostile for mass people to be embodied.

Most of the global refugee and displaced people nowadays come from Asian and African countries and Latin American countries (Leaning, Spiegel, \& Crisp, 2011). It was about fifteen million people who became homeless during the devastating WW-II. After World War-II, South Asia became the derivative of conflict due to the declaration of partition in British India after two-hundred years of colonial rule. A bloody two-nation theory triggered massacres and the bloodiest disruptions in history that made them independent and produced fifteen-to-twenty million homeless people again and rapped at least 75000 women (Ahmed 2002; Butalia, 2000; Bhopal, 2020) since the leaders failed to united British India for several reasons (Pandey, 1969). East Pakistan, now Bangladesh, became the colony of Pakistan as the majority of its population was Muslim but owing to socio-cultural diversity and countless deprivation made them disgruntled against Pakistan. In politics of deprivation typically minorities, i.e., religious, linguistics, race, culture or sectarian, become the central targets of state-borne or state-sanctioned discrimination and violence (Ahmed, 2002) since individuals and social groups are imbedded in loose social fabrication and system and get trapped (Lake \& Rothchild, 1998). Bangladesh comes into being as an independent sovereign country by a bloody nine-month war against Pakistan in 1971 that mimic 10 million refugees at that time (Schanberg, 1971; UNHCR, 2000a, 2000b) who were hosted by India without any legal framework as it was not the signatory of 1951 convention and 1962 protocol (Chimni, 1994) at that time. The history of refugee and displaced people later on continued in different parts of the world due to war, conflict, and persecution. The twentieth-century ended with the Rwanda genocide. Like Afghanistan, Syria, Myanmar, South Sudan, Somalia, Congo, Sudan, Iraq, Eritrea, Central African Republic are the origin of refugees and displaced people where Venezuela has become the youngest partner with about 6.5 million displaced people at the end of 2020 (UNHCR, 2020a).

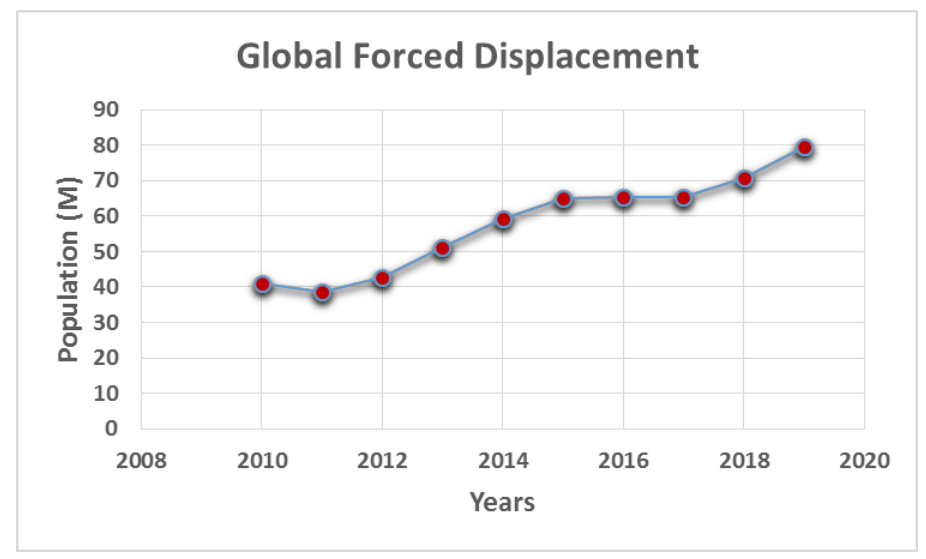

Figure 1. Global Trends, Forced Displacement in 2019 (UNHCR, 2020b)

Syrian pre-war population estimation was 22 million, the United Nations Human Rights Council (UNHRC) 
identified 5.5 million Syrian refugees outside of Syria while 6 million people were internally displaced in 2018 . Most of the Syrian refugees who fled due to the civil war that persists in the Middle East are in Turkey (3.6 million) where they made it the largest refugee-hosting country in the world. While 6.2 million Syrians people internally displaced due to the crisis. Lebanon, Jordan, and Iraq are also hosting Syrian refugees in their countries (Gallien, 2018a). Meanwhile, about 1.4 million refugees returned to their homes where they are facing formidable conditions comprising the absence of infrastructure and amenities with the risk of explosives (Huber $\&$ Reid, 2018). This proves the actual figure, of Syria with many others, and the real scenario of reaching asylum seekers towards "Fortress Europe" (Gallien, 2018a). However "By engaging in wars abroad, participating in the destruction of entire regions and societies, exploiting cheap labor and natural resources, and supporting autocratic and authoritarian regimes, these democracies create the very refugees that they then reject (Gallien, 2018a)."

The response of European countries varied about the refugee and displace people on welcoming them as refugees and migrants while many of them tried to pretend the crisis. Many countries of Europe denied receiving the refugees while few have taken additional than their fair share. A major part of refugees in Europe is from Syria who came after the violent civil war. Tenacious and uninterrupted violence and turbulence in Iraq and measurable Afghanistan and conflict, violence, political instability in Africa along with food crises forced people in search of a better life. When Gallien stated about the refugees (2018b) that, "they are not outsiders but are the consequence of western politics." Political instability, civil war, and conflict in the poorest countries of Africa left their basic health infrastructure severely damaged with no education of youth and children and disappeared their people from their homeland as refugees or IDPs.

\subsection{Gradual Budget Deficiency for the Refugees and Displaced People}

The twenty first century observed massive global migration, millions on the move, and the largest refugee crisis since the Second World War which sparks fierce debate in Western countries over whether to open the floodgates or shut the door. This issue is the biggest challenge facing countries across Europe today bringing refugees to the United States even a small number of them is extraordinarily expensive but is it really how much does welcoming a refugee or an immigrant. COVID-19 pandemic can trigger the issue once again due to the public health and national security of these regions.

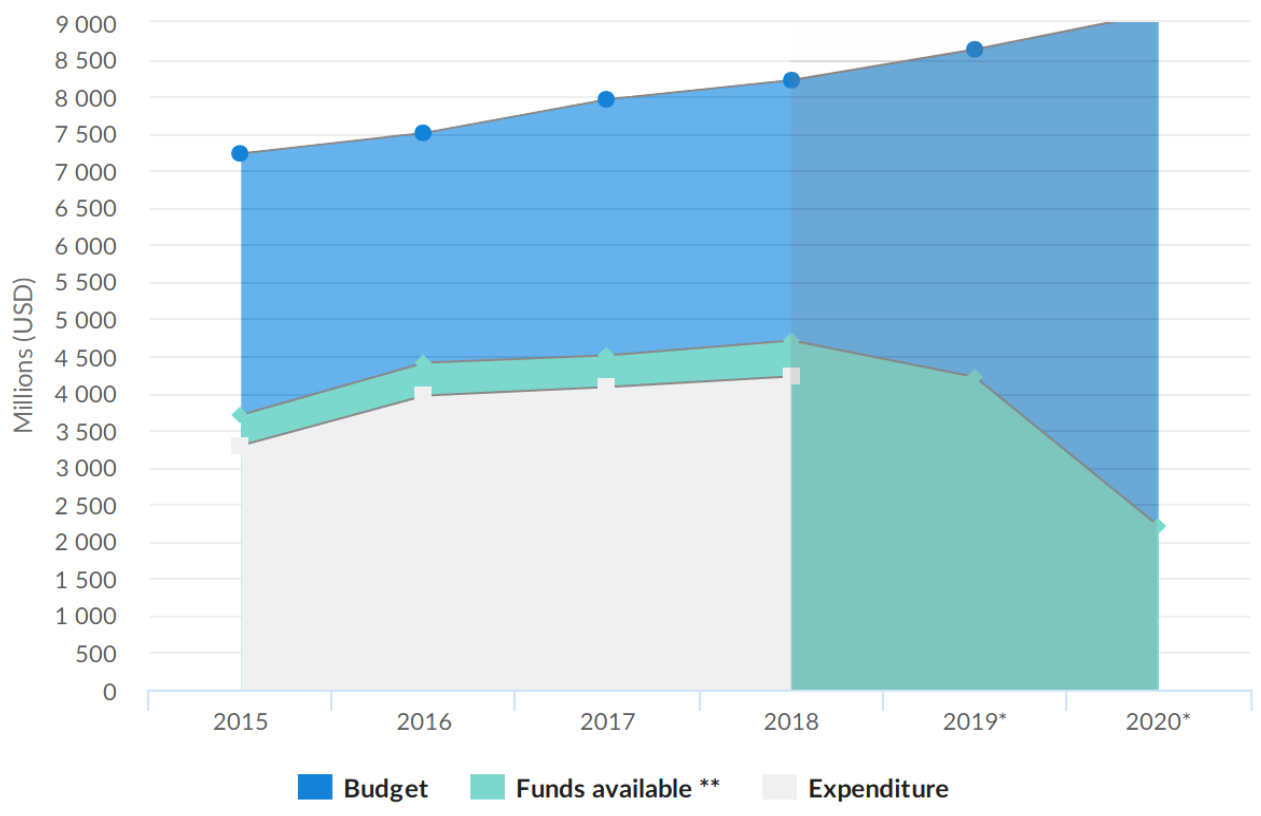

Figure 2. Budget Contribution in Different Years ${ }^{1}$

According to the report of UNHCR, the United States of America (USA) and the European Union (EU) donate the lion's portion of funds for refugee management. However, these countries are adversely affected by this

\footnotetext{
${ }^{1}$ UNHCR, Financing; http://reporting.unhcr.org/financial\#_ga=2.235807873.1446072355.1592317966-827901760.15756235
} 14 (Accessed on June 14, 2020). 
COVID-19 pandemic. These may create pressure on the refugee crisis for their economic and local policy changes due to the adverse effect of pandemics (Garrett, 2020). Besides, the USA, Australia, and the EU are the leading destinations not only for usual migration but also for immigrants from the refugees, asylum seekers, and displaced peoples.

The process of receiving refugee and asylum seeker might be lengthy under this situation, and it may lead to the further crisis in the countries which are hosting them as they have lack of policies (Satterthwaite et al., 2019; Coddington, 2018). Besides concern has increased about the costs and difficulties of resettlement, particularly of third-world refugees alongside their economic inability. Resurface of unemployment in developing, developed, and European countries also put pressure on policies on international immigrants and asylum seekers. The downturn of their economies owing to the current COVID-19 epidemics can also adversely affect the developing country's economy as their people will not be able to earn in and outside of their economy that may lead their economy to become fragile (Martinez-Juarez et al., 2020; Ahmed et al., 2020; Vos, Martin, \& Laborde, 2020). Still, there is a budget deficit in the developing world for humanitarian support for their people as well as the refugees [Figure-2] it would be more challenging for them in the next year due to the current stagnancy of the world economy. Then the question is that how they mitigate the demands on the basic needs where numbers of support systems need assistance from the external side? On the other hand, newly displaced people are also adding to the refugee and displaced world. These people also need the same assistance for their livelihoods. However, the funding is declining, and the budget increasing the last few years.

Among the top ten donors who are funding through the United Nations High Commissioner for Refugees (UNHCR) for refugees, the USA is the first among the top ten while the others are European countries with EU expect Japan (UNHCR 2020b) But, unfortunately, these countries of the world are adversely infected and suffering from the COVID-19 pandemics which will indirectly reduce their pressure to refugee and asylum seekers however we might not be surprised if the things go opposite which will be a new challenge for the old players where they have to play the same game in a new rule that is still unexplored. The budget gap for refugees are extending every year according to the report of UNHCR and which is highest in the last five years and almost double from the previous year's budget besides, about 6.5 million new displaced people are going to add rendering the prediction report of UNHCR from Venezuela in 2020 (UNHCR, 2019, 2020a). Now the challenges appear, also for refugees, when the corona pandemics overwhelms all over the world.

\subsection{Livelihoods and Food Security for the Refugees and Displaced People}

Societal well-being largely depends on the good health of its population as it is the driving force for the vibrant and wealthy economy (Kagame and Ghebreyesus 2019). The Health system plays a crucial role at a different level of a nation- at the community level, it underpins productivity, while at the national level it is vital to security, resilience, and growth. Well-operating health systems empower countries to respond, and recover from, natural and human-made disruptions. After the outbreak of the contemporary COVID-19 pandemic health risk like climate change, appeared as an 'expensive and expanding transnational challenge' (World Economic Forum, 2020). It is necessary to look into the fitness of the existing health system and its existing methods and organizations to maintain and accelerate the growth and development and get to work with the emerging threats. Because failure in the health system on adaption and mitigation of vulnerabilities results in economic and political crises, social ruptures, and state-on-state conflict (World Economic Forum, 2020). Political instability, inequality, conflict, and the adverse impact of climate change have altogether contributed persistently to raise the numbers of hunger ${ }^{2}$ and food insecurity around the world. However, in the last 20 years, few nations made remarkable progress in food production and dropping the number of hunger such as Ethiopia, Rwanda while in the Central African Republic hunger remains extremely alarming. Many countries of the world have inadequate assessable data for $\mathrm{GHI}^{3}$ (Global Hunger Index) and widespread hunger i.e., Syria, Somalia, Burundi, South Sudan, Democratic Republic of Congo. As a result, people from these countries fled from their homes not just because of the food insecurity but also for war, conflict, and violence and become refugees while many are internally displaced (Gallien, 2018b). These issues also contributed to a decrease in the state capacity (Hanson \&

\footnotetext{
2 'Hunger is usually understood to refer to the distress associated with a lack of sufficient calories. The Food and Agriculture Organization of the United Nations (FAO) defines food deprivation, or undernourishment, as the consumption of too few calories to provide the minimum amount of dietary energy that each individual requires to live a healthy and productive life, given that person's sex, age, stature, and physical activity level'. (FAO, 2017 and GHI, 2019).

3 'The Global Hunger Index (GHI) is a tool designed to comprehensively measure and track hunger at global, regional, and national levels.'
} 
Sigman, 2013) as a whole for further crises. It is awful that climate change and conflict impeding food security in vulnerable regions of the world after a decade of persistent improvement in diminishing global hunger. So the laborious achievements nowadays stand under threat of being reversed as the hungry persons increased from 785 million to 822 million from 2015 to 2018.

Global Hunger Index (GHI) score reveals the country's indicating values in performances in reducing hunger concerning other countries. The score resulting higher in the GHI report directs higher "level of child wasting, reflecting acute undernutrition; child stunting, reflecting chronic undernutrition; and/or child mortality, reflecting children's hunger and nutrition levels, as well as other extreme challenges facing the population" (GHI, 2019).

Table 1. Status of Countries in the Global Hunger Index (GHI) dealing with Refugees and IDPs

\begin{tabular}{|c|c|c|c|c|}
\hline \multicolumn{5}{|c|}{ GHI (Global Hunger Index) Severity Scale } \\
\hline $\begin{array}{l}\leq 9.9 \\
\text { low }\end{array}$ & $\begin{array}{l}10.0-19.9 \\
\text { moderate }\end{array}$ & $\begin{array}{c}20.0-34.9 \\
\text { serious }\end{array}$ & $\begin{array}{c}35.0-49.9 \\
\text { alarming }\end{array}$ & $\begin{array}{c}\geq \\
\geq 50.0 \\
\text { extremely alarming }\end{array}$ \\
\hline $\begin{array}{l}\text { Colombia }(6.7) \\
\text { Turkey }(<5)\end{array}$ & $\begin{array}{l}\text { Venezuela* (16.9) } \\
\text { South Africa (14) }\end{array}$ & $\begin{array}{c}\text { Sudan* (32.8) } \\
\text { Congo Republic (31) } \\
\text { Uganda (30.6) } \\
\text { Rwanda (29.1) } \\
\text { Ethiopia (28.9) } \\
\text { Pakistan (28.5) } \\
\text { Bangladesh (25.8) } \\
\text { Kenya (25.2) } \\
\text { Myanmar* (19.8) }\end{array}$ & Afghanistan* (33.8) & $\begin{array}{l}\text { The central African } \\
\text { Republic* (53.6) }\end{array}$ \\
\hline Not available data & Burundi*, The De & ratic Republic of the $C$ & $\begin{array}{l}\text { Eritrea*, Somalia* } \\
\text { blic* }\end{array}$ & udan*, the Syrian Arab \\
\hline
\end{tabular}

Source: Global Hunger Report, 2019 [* indicates the country of origin for refugees and displaced people.]

Eighty percent of the displaced people are from the regions where there is predominant acute food insecurity and malnutrition. Among the displaced people forty percent (UNHCR, 2020b) are children which is why a serious issue for future sustainability not only for the food, health, and the economy (Wiesmann et. al., 2006) but also the society as a whole as pandemics nowadays crossed the geographic and political boundaries. Generally, a high GHI score can be an indication of a lack of food, a poor-quality diet, inadequate child caregiving practices, an unhealthy environment, or all of these factors.

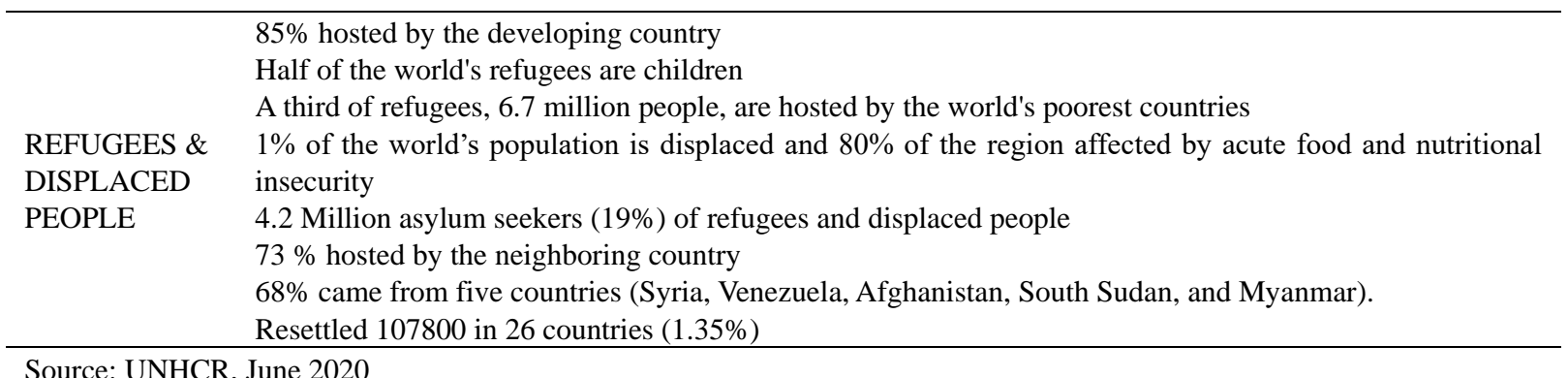

World Food Program (WFP) and Food and Agriculture Organization (FAO) are principals with other national and international organizations to ensure the food security for the refugees. Deterioration of agricultural production increases the price volatility, as history shows it can trigger instability and deteriorate the long-term security (World Economic Forum, 2020).

The COVID-19 pandemic disrupts the food production as a whole and the food supply chain is also fractured and jeopardized due to the Covid-19 pandemic that based on long-distance even in the first world country USA (Goffman, 2020) though it is problematic to realize as it is multifaceted and interdependent (Markard \& Rosenbloom, 2020).

\subsection{Pandemic and Public Health: Potential Challenges for Refugees and Displaced People}

The public health sector is passing stressful situations nowadays due to a double burden in the health sector as communicable infectious diseases supersede the non-communicable diseases as the primary cause of death after the COVID-19 outbreak. There is no doubt that increasing life expectancy, coupled with 'the economic and societal costs of managing chronic diseases has put healthcare systems in many countries under stress' (World Economic Forum, 2020). However these infectious diseases also indirectly add more vulnerability to 
non-communicable diseases i.e., cardiac, respiratory, and mental health (Seagle et al., 2020). In the $21^{\text {st- }}$ century public health concern for refugees and internally displaced people (IDPs) become more challenging and resulting in more vulnerabilities, however, it is addressed several times for the equity in public health especially during conflict and pandemics (Leaning, Spiegel, \& Crisp, 2011; Bhopal, 2020; Chuah et al., 2018).

Public health facilities are lean for the refugees and internally displaced people in their camps in different countries however many camps have limited support for their health related issues which are inadequate in quality, numbers, and expertise. Many of them are not well equipped with logistics for emergency support. Refugee and displaced people are vulnerable and susceptive to different infectious diseases as almost 50 percent of them are children and all are not under general health care facilities i.e., immunization, vitamin tablets, etc. Besides, homeless refugee and displaced people are at 'heightened risk of disease exposure and transmission due to their reliance on precarious water, sanitation, and hygiene facilities' (Panhuis, 2018). That is why the children of these communities are most vulnerable today (Oberg, 2019). It is found that refugee and displaced children are living with serious health problems than the non-refugee children and mental trauma is also prevailing among the refugee children as well as the youth and adults (Oberg, 2019). Cardiac diseases, respiratory diseases, acute asthma with other serious diseases are also common among them with malnutrition for both children and adults due to food insecurity, and lack of proper diet (Oberg, 2019; Group, 1995; Toole \& Waldman, 1997).

A considerable philanthropic discussion of 'public health equity relating to refugees focuses on resource allocation, which is a central concern in distributional ethics and notions of justice' (Leaning, Spiegel, \& Crisp, 2011). As refugees have multiple medical issues and required treatment from general practitioners and specialized doctors for months or even more and to get the best patient outcome to require a coordinated health system that is often not available, resulting in fragility (Truelove et al., 2020). Covid-19 pandemics declared the global emergency, on January 30, 2020, by World Health Organization (WHO), and spotlights on the marginalization and barriers in health service while 'strangers in need' (Wilson \& Brown, 2009) because refugees and displaced peoples are prone to 'rapid and devastating effects' (Lau et al., 2020). Many international humanitarian organizations are working on several issues of refugees and IDPs however still many questions are there on public health while it is recommended to include these communities into the responses of pandemic (Fricker, 2017; Orcutt et al., 2020). Because 'front-line relief workers in complex emergencies are often volunteers recruited by NGOs who sometimes lack specific training and experience in emergency relief' (Toole $\&$ Waldman, 1997). They need real-world experience in multidimensional aspects 'including food and nutrition, water and sanitation, disease surveillance, immunization, communicable disease control, epidemic management, and maternal and child health care' (Toole \& Waldman, 1997). Besides, refugees also have a substantial knowledge gap in maternal and reproductive health with poor infant feeding care practice and diet diversity. There is a meager 'water supply, poor hygiene and sanitation facilities and low vaccination rates pose a risk for disease outbreaks and malnutrition' in refugee camps than mass people (UNHCR, 2019; Truelove et al., 2020).

Public health is endangered due to zoonoses, which are caused by zoonotic pathogens and transmitted to humans from animals and hampers wellness. Expansion and acceleration of global trade, human movement, and population explosion intensify the evolution and adaption of the zoonotic pathogens in new hosts and ecosystems that make the control of zoonoses very challenging. Wildlife is a major animal reservoir for zoonotic diseases and is considered as the source of $75 \%$ of emerging diseases that pose a threat to human health. The epidemiology of diseases is linked with wildlife and influenced by other factors of agro-climate conditions, host abundance, movement of pathogens/vector/animals, migratory birds, and anthropogenic factors (Wilke \& Haas, 1999; Daszak et al., 2001; Bengis et al., 2004; Patz et al., 2004). As a result, refugees and displaced people from African and other infected regions are at threat to migrate and or seek asylum in any developed country in the coming days. Covid-19 pandemic outbreak challenged the dramatic gains in the health sector and stirred all government, public health organizations, and other allied institutions to pay attention to diagnosis and detecting infected patients (Haleem, Javaid, \& Vaishya, 2020). Migrants on their way to the destination cannot leave their 'morbidity and health burden frequently migrate with them (Oberg, 2019)' which is a great concern for western refugees and migrants receiving countries especially during a pandemic and hazardous public health conditions. The World Health Organization (WHO) projected \$675 million urgent funds for "Priority Public Health Measures" for three months while the UN secretary general launched \$2 billion for global support. However, there is no specific declaration to support these vast populations who are not under any formal institutional framework for their health.

It is also claimed by different scholars that human migration, including refugees and displaced people, can be a cause of the spread of zoonotic diseases (McNeill \& McNeill, 1998; Morse, 2001; Daszak et al., 2001; Venkatesan et al., 2010) which can trigger the political leaders to impose legal restrictions in human movement 
and refugee or asylum seekers. Travelling also restricted due to the outbreak of the pandemic in different countries (Haleem, Javaid, \& Vaishya, 2020) as they are the substantial bearer of novel cases to further countries (Rodríguez-Morales et al., 2020), many of the developing countries are badly affected by the COVID-19 virus and people are not allowed to travel in many developed countries including the migrants, refugee and asylum seekers. So it can be said that boundaries are fluctuating with government strategies after pandemic that recommend a 'humanitarian border topologically' (Kallio, Häkli, \& Pascucci, 2019) approach in formulating government policies for the refugees and displaced people. Because 'existing health risks resurge and new ones emerge, humanity's past successes in overcoming health challenges are no guarantee of future results' (World Economic Forum, 2020) and we need "international humanitarian order" (2011) as Michael Barnett described. So, these vulnerable groups living in the poorest condition with insufficient medical support for testing, care, and treatment lead to further suffering (Martinez-Juarez et al., 2020). So it is expected from the humanitarian point of view that refugees and displaced people should give attention to the leaders of the world (Bhopal, 2020).

\subsection{Refugee and Environment: Bio-diversity and Poverty Connectivity}

The tremendous explosion of the human population closely concomitant with bio-diversity and central to exceptional alteration in the terrestrial and aquatic ecosystem (Swanson et al., 2004). It is widely recognized that pandemics have had a strong connection with bio-diversity likewise Covid-19 has coincided and linked with urbanization, globalization, and climate change (Everard et al., 2020; Whiting, 2020). Compared to 2005 to 2030 , the global projected output of biofuels was 20 million tonnes of oils in 2005 to 92 million in 2030. Biofuels are produced on 1 percent of arable lands of the world which was projected to increase four percent by 2030 while the largest escalation materializing in Europe and the United States (Swanson et al., 2004). Dams and diversions fragmented rivers around the world about sixty percent and result in floods, disruption of flows, and hindering the migration routes.

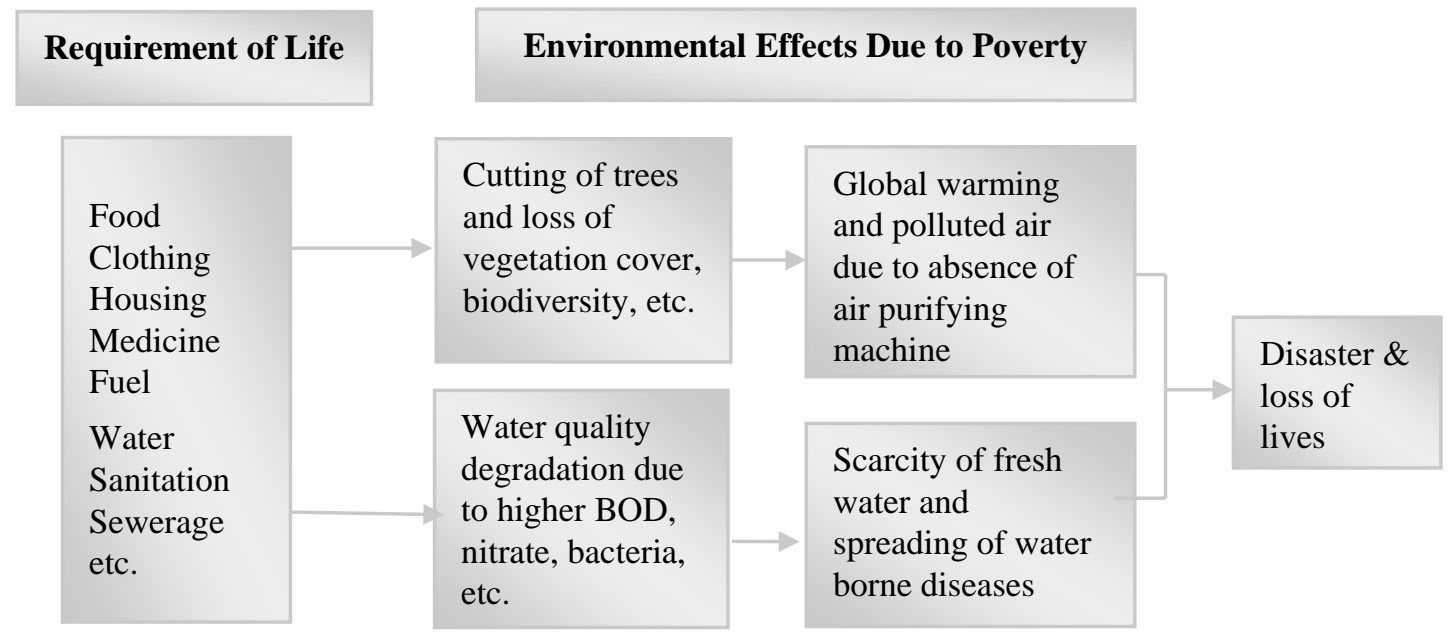

Figure 3. The connection between Environment and Poverty (Roy, Chowdhury, \& Rahman 2007)

Refugee and displaced people are always in threat to loss of their ethnic and spiritual values, traditional knowledge and practice in their voyages that can trigger the increasing pressure on bio-diversity i.e., the Rohingya influx and camp shift in protected area of forest in Bangladesh witnessed extensive eco-environmental destruction in that region where around 4000 acres of hilly forest cleared due to vertical expansion of refugee camp in August 2017 (Hassan et al., 2018). "Widespread anthropogenic changes to the environment have altered patterns of human disease and increased pressures on human well-being. The loss of genetic diversity, overcrowding, and habitat fragmentation all increase susceptibility to disease outbreaks. Biodiversity is the source of many cures (UNEP, 2007)." It is necessary to count and consider the value of the ecosystem in policy making by the leaders as pandemics overwhelmed the world community nowadays irrespective of economy, region, and culture. However sustainable development called for interventions through the ecosystems and collaborating "population management, human health, food security, human settlements and land use (Swanson et al., 2004)". As a result, it is critical to coordinate the diverse levels for leveraging significant changes in the coming days that require the diffusion of policy initiatives (Gilardi \& Wasserfallen, 2019; Swanson et al., 2004; Panayotou, 1998) by the world leaders.

COVID-19 pandemic invoked the pressure on challenges for the Asian and African nations due to the diversity of challenges along with economic fragility, political instability, refugee and migrants crisis, and overwhelming 
climate change challenges (Chattu \& Chami, 2020) to promote the development. The current pandemic can be a major threat to the lives of refugees and displaced people as the straight outcome of poverty, disease is a major hindrance to development. Humanitarian aids are crucial for these people as many of the hosting countries are economically insolvent to spend enough for refugees and displaced people around the world. But this aid is a short-term solution for them when the COVID-19 pandemic jeopardized both the short-term and long-term opportunities for these groups of people due to insufficiency of the humanitarian fund and travel restrictions and migration policy changes. In addition, it can also linger the migration to a third country as asylum seekers or a registered refugee where they could earn the right of their economic opportunity and self-sufficiency for social well-being.

\section{Conclusions}

Refugee and displaced people are not welcomed positively around the world. They are not confined to one country and can have a detrimental effect on neighboring countries as well which requires an immediate response. Even though the issue of refugee and displaced people is not afforded the priority like economics but for long-run global and regional security, the state and government should consider it a priority because it overwhelmingly incapacitated millions of people in camps. It is also unfolded the background story of the refugee and displaced people once they have been treated as the by-product of economic and military war in different countries. COVID-19 pandemic can be an opportunity for innovations in governance and, not only in refugee but also, restoring of the socio-cultural, socio-political, and socio-historical estrangements that breed vulnerability in a specific marginalized group (Orcutt et al., 2020). That is why we should take into consideration the "pervasive failure to consult members of vulnerable groups and their representative organizations during crisis response" (Eckenwiler et al., 2018; Orcutt et al., 2020). Because social inclusion and integration aspects required a one-stop service for them which is not always practical for a host country to offer due to several constraints. As refugees have to deal with safety, jobs for surviving, family unifications so they need flexibility and persistent support for their family members and their livelihoods. This pandemic affects the whole world much more than any other epidemics ever. There is a danger that they will be largely forgotten in the present and, worse, that they will be unfairly blamed in the aftermath of the pandemic, once control has been achieved in most populations but is still lingering in these (Bhopal, 2020). The sufferings of developing refugee (hosting) countries are much more due to their inability to the economy, and management and governance of the pandemics. It also applies them to refugee management as there are policy gaps and no such previous experience in their countries. The administrative and practical backing comprises legal and institutional issues, more specifically the bureaucratic assistance, aid them to find affordable accommodation in or outside of the camp. Now it is a big challenge for states how they will continue and play their role in the post-COVID-19 era along with other local, regional, and international GOs and NGOs to provide humanitarian support and development for the refugees and displaced people (Olliff, 2018). Refugees can be dyed as a new political dimension in world politics after the COVID-19 pandemic which can reshape the human and political geography in and outside of the sovereign polity. However, COVID-19 pandemics again indicate the synergistic performances from the government and within the government around the world. Because the causes of conflict are much the same as they were in the past however is that the world reacts to the conflict very differently (Coker, 2002).

\section{Acknowledgments}

This paper is not funded by any sources. I would like to thank my colleague Dr. Nahid Sattar, Department of Agricultural Economics, Bangladesh Agricultural University, Mymensingh-2202, Bangladesh, and Professor Dr. Linda Briskman, Western Sydney University, Australia for their comments on my primary draft to finalize the manuscript.

\section{Reference}

Ahmed, F., Ahmed, N. E., Pissarides, C., \& Stiglitz, J. (2020). Why Inequality Could Spread COVID-19. The Lancet Public Health, 5(5), e240. https://doi.org/10.1016/S2468-2667(20)30085-2

Ahmed, I. (2002). The 1947 Partition of India: A Paradigm for Pathological Politics in India and Pakistan. Asian Ethnicity, 3(1), 9-28. https://doi.org/10.1080/14631360120095847

Albon, D., Soper, M., \& Haro, A. (2020). Potential implications of the COVID-19 pandemic on the homeless population. Chest, 158(2), 477-478. https://doi.org/10.1016/j.chest.2020.03.057

Benezer, G., \& Zetter, R. (2014). Searching for Directions: Conceptual and Methodological Challenges in Researching Refugee Journeys. J. of Refugee Studies, 28(3), 297-318. https://doi.org/10.1093/jrs/feu022

Bengis, R. G., Leighton, F. A., Fischer, J. R., Artois, M., Morner, T., \& Tate, C. M. (2004). The role of wildlife in 
emerging and re-emerging zoonoses. Revue scientifique et technique-office international des epizooties, 23(2), 497-512.

Barnett, M. (2011). Empire of humanity: A history of humanitarianism. Cornell University Press.

Bhopal, R. S. (2020). COVID-19: Immense Necessity and Challenges in Meeting the Needs of Minorities, Especially Asylum Seekers and Undocumented Migrants. Public Health, no. May. https://doi.org/10.1016/j.puhe.2020.04.010

Butalia, U. (2000). The Other Side of Silence: Voices from the Partition of India. London: Hurst \& Company. Retrieved from https://books.google.hu/books/about/The_Other_Side_of_Silence.html?id=JGklJI4eiNIC\& printsec $=$ frontcover \&source $=\mathrm{kp} \_$read_button\&redir_esc $=\mathrm{y} \# \mathrm{v}=$ onepage $\& \mathrm{q} \& \mathrm{f}=\mathrm{false}$.

Chattu, V. K., \& Chami, G. (2020). Global Health Diplomacy Amid the COVID-19 Pandemic: A Strategic Opportunity for Improving Health, Peace, and Well-Being in the CARICOM Region-A Systematic Review. Social Sciences, 9(5), 88. https://doi.org/10.3390/SOCSCI9050088

Chimni, B. S. (1994). The Legal Condition of Refugees in India. Journal of Refugee Studies, 7(4), $378-401$. https://doi.org/10.1093/jrs/7.4.378

Chuah, F. L. H., Tan, S. T., Yeo, J., \& Legido-Quigley, H. (2018). The Health Needs and Access Barriers among Refugees and Asylum-Seekers in Malaysia: A Qualitative Study. International Journal for Equity in Health, 17(1), 120. https://doi.org/10.1186/s12939-018-0833-x

Coddington, K. (2018). Landscapes of refugee protection. Transactions of the Institute of British Geographers, 43(3), 326-340. https://doi.org/10.1111/tran.12224

Coker, C. (2002). Waging war without warriors?: The changing culture of military conflict. Lynne Rienner Publishers.

Crawley, H., Düvell, F., Mcmahon, S., \& Jones, K. (2016). Unpacking a Rapidly Changing Scenario: Unravelling the Mediterranean Migration Crisis (MEDMIG) Migration Flows, Routes and Trajectories across the Mediterranean, no. January.

Daszak, P., Cunningham, A. A., \& Hyatt, A. D. (2001). Anthropogenic environmental change and the emergence of infectious diseases in wildlife. Acta tropica, $103-116$. https://doi.org/10.1016/S0001-706X(00)00179-0

Duncan, C. J. (2005). What Caused the Black Death? Postgraduate Medical Journal, 81(955), 315-320. https://doi.org/10.1136/pgmj.2004.024075

Eckenwiler, L., Hunt, M., Leach Scully, J., \& Wild, V. (2018). Understanding and Operationalizing Vulnerability in International Humanitarian Health Organisations. European Journal of Public Health, 28(suppl_1). https://doi.org/10.1093/eurpub/cky048.181

Everard, M., Johnston, P., Santillo, D., \& Staddon, C. (2020). The role of ecosystems in mitigation and management of Covid-19 and other zoonoses. Environmental Science \& Policy. https://doi.org/10.1016/j.envsci.2020.05.017

Fricker, M. (2017). Evolving concepts of epistemic injustice. In I. J. Kidd, J. Medina, \& G. Pohlhaus Jr. (Eds.), Routledge Handbook of Epistemic Injustice. Routledge Handbooks in Philosophy (pp. 53-60). Routledge.

Gallien, C. (2018a). Forcing Displacement: The Postcolonial Interventions of Refugee Literature and Arts. Journal of Postcolonial Writing, 54(6), 735-750. https://doi.org/10.1080/17449855.2018.1551268

Gallien, C. (2018b). Refugee Literature: What Postcolonial Theory Has to Say. Journal of Postcolonial Writing, 54(6), 721-726. https://doi.org/10.1080/17449855.2018.1555206

Garrett, T. M. (2020). COVID-19, Wall Building, and the Effects on Migrant Protection Protocols by the Trump Administration: The Spectacle of the Worsening Human Rights Disaster on the Mexico-U.S. Border. Administrative Theory \& Praxis, 42(2), 240-248. https://doi.org/10.1080/10841806.2020.1750212

Gilardi, F., \& Wasserfallen, F. (2019). The Politics of Policy Diffusion. European Journal of Political Research, 58(4), 1245-1256. https://doi.org/10.1111/1475-6765.12326

Gillespie, M., Osseiran, S., \& Cheesman, M. (2018). Syrian Refugees and the Digital Passage to Europe: Smartphone Infrastructures and Affordances. Social Media + Society, 4(1), 205630511876444. https://doi.org/10.1177/2056305118764440

GHI. (2019). Global Hunger Index, 2018. Dublin/Bonn: Concern Worldwide and Welthungerhilfe. 
Zapata, G. P., \& Guedes, G. R. (2019). Population Mobility in the Twenty-First Century: Trends, Conflicts, and Policies]Mobilité de La Population Au XXIe Siècle: Tendances, Conflits et Politiques | N-IUSSP., N-IUSSP Online New Magazine, January 7. 2019. Retrieved from https://www.niussp.org/article/population-mobi lity-in-the-twenty-first-century-trends-conflicts-and-policiesmobilite-de-la-population-au-xxie-siecle-tendan ces-conflits-et-politiques/

Goffman, E. (2020). In the Wake of COVID-19, Is Glocalization Our Sustainability Future? Sustainability: Science, Practice and Policy, 16(1), 48-52. https://doi.org/10.1080/15487733.2020.1765678

Goot, M., \& Watson, I. (2011). Population, immigration and asylum seekers: patterns in Australian public opinion. Population, 2010,11. Retrieved from https://www.ianwatson.com.au/pubs/parliamentary_library_ population.pdf

Group, G. E. (1995). Public health impact of Rwandan refugee crisis: what happened in Goma, Zaire, in July, 1994?. The Lancet, 345(8946), 339-344. https://doi.org/10.1016/S0140-6736(95)90338-0

Haddad, E. (2001). Who Is (Not) a Refugee? In The Refugee in International Society, 23-46. Cambridge University Press. https://doi.org/10.1017/CBO9780511491351.003

Haleem, A., Javaid, M., \& Vaishya, R. (2020). Effects of COVID-19 Pandemic in Daily Life. Current Medicine Research and Practice, 10(2), 78-79. https://doi.org/10.1016/j.cmrp.2020.03.011

Hanson, J. K., \& Sigman, R. (2013, September). Leviathan's Latent Dimensions: Measuring State Capacity for Comparative Political Research. Manuscript, Maxwell School of Citizenship and Public Affairs, Syracuse University, 1-41. Retrieved from http://faculty.maxwell.syr.edu/johanson/papers/hanson_sigman13.pdf

Hassan, M. M., Smith, A. C., Walker, K., Rahman, M. K., \& Southworth, J. (2018). Rohingya refugee crisis and forest cover change in Teknaf, Bangladesh. Remote Sensing, 10(5), 689. https://doi.org/10.3390/rs10050689

Holborn, L. W. (1975). Refugees: A Problem of Our Time. Metuchen, New Jersey, Scarecrow Press.

Huber, C., \& Reid, K. (2018). Forced to Flee: Top Countries Refugees Are Coming From. World Vision. Retrieved from https://www.worldvision.org/refugees-news-stories/forced-to-flee-top-countries-refugeescoming-from

Jesson, J., Matheson, L., \& Lacey, F. M. (2011). Doing Your Literature Review: Traditional and Systematic Techniques. Sage.

Johns, F. E. (2004). The Madness of Migration: Disquiet in the International Law Relating to Refugees. International Journal of Law and Psychiatry, 27(6), 587-607. https://doi.org/10.1016/j.ijlp.2004.08.003

Kagame, P., \& Ghebreyesus, T. A. (2019). History shows health is the foundation of African prosperity. Financial Times.

Kallio, K. P., Häkli, J., \& Pascucci, E. (2019). Refugeeness as Political Subjectivity: Experiencing the Humanitarian Border. Environment and Planning C: Politics and Space, 37(7), 1258-76. https://doi.org/10.1177/2399654418820915

Katie Savin, L. G.-G. (2020). Confronting Disability Discrimination During the Pandemic. Retrieved June 22, 2020 from https://www.thehastingscenter.org/confronting-disability-discrimination-during-the-pandemic/

Kay, M., Jackson, C., \& Nicholson, C. (2010). Refugee Health: A New Model for Delivering Primary Health Care. Australian Journal of Primary Health, 16(1), 98. https://doi.org/10.1071/PY09048

Lake, D. A., \& Rothchild, D. (1998). Spreading Fear: The Genesis of Transnational Ethnic Conflict. In D. A. Lake, \& D. Rothchild (Eds.), The International Spread of Ethnic Conflict. Princeton University Press, Princeton, New Jersey.

He, X., Lau, E. H., Wu, P., Deng, X., Wang, J., Hao, X., ... Mo, X. (2020). Temporal dynamics in viral shedding and transmissibility of COVID-19. Nature medicine, 26(5), 672-675.

Leaning, J., Spiegel, P., \& Crisp, J. (2011). Public health equity in refugee situations. Conflict and Health, 5(1), 1-7. https://doi.org/10.1186/1752-1505-5-6

McNeill, W. H., \& McNeill, W. (1998). Plagues and peoples. Anchor Press/ Doubleday.

Manderson, L., \& Levine, S. (2020). COVID-19, Risk, Fear, and Fall-Out. Medical Anthropology, March, 1-4. https://doi.org/10.1080/01459740.2020.1746301

Markard, J., \& Rosenbloom, D. (2020). A tale of two crises: COVID-19 and climate. Sustainability: Science, 
Practice and Policy, 16(1), 53-60. https://doi.org/10.1080/15487733.2020.1765679

Martinez-Juarez, L. A., Sedas, A. C., Orcutt, M., \& Bhopal, R. (2020). Governments and international institutions should urgently attend to the unjust disparities that COVID-19 is exposing and causing. $E$ Clinical Medicine. https://doi.org/10.1016/j.eclinm.2020.100376

Morse, S. S. (2001). Factors in the emergence of infectious diseases. In Plagues and politics (pp. 8-26). Palgrave Macmillan, London.

Mubarak, N. (2020). Corona and Clergy - The Missing Link for Effective Social Distancing in Pakistan: Time for Some Unpopular Decisions. International Journal of Infectious Diseases, 95, 431-432. https://doi.org/10.1016/j.ijid.2020.04.067

Murray, S. B., \& Skull, S. A. (2005). Hurdles to health: Immigrant and refugee health care in Australia. Australian Health Review, 29(1), 25-29.

Nussbaum, M. C. (2009). Frontiers of justice: Disability, nationality, species membership. Harvard University P.

Oberg. (2019). The Arc of Migration and the Impact on Children's Health and Well-Being Forward to the Special Issue-Children on the Move. Children, 6(9), 100. https://doi.org/10.3390/children6090100.

Olliff, L. (2018). From Resettled Refugees to Humanitarian Actors: Refugee Diaspora Organizations and $\begin{array}{lllll}\text { Everyday Humanitarianism. New } & \text { Political }\end{array}$ https://doi.org/10.1080/07393148.2018.1528059

Orcutt, M., Patel, P., Burns, R., Hiam, L., Aldridge, R., Devakumar, D., ... \& Abubakar, I. (2020). Global call to action for inclusion of migrants and refugees in the COVID-19 response. The Lancet, 395(10235), 1482-1483. https://doi.org/10.1016/S0140-6736(20)30971-5

Pandey, B. N. (1969). The Break-up of British India. Macmillan, London.

Panayotou, T. (1998). Instruments of change: Motivating and financing sustainable development (p. 23). London: Earth scan Publications Ltd.

Panhuis, J. (2018). Neglected populations, neglected diseases. European Heart Journal, 39(14), 1124-1127. https://doi.org/10.1093/eurheartj/ehy139

Patz, J. A., Daszak, P., Tabor, G. M., Aguirre, A. A., \& Pearl, M. (2004). Unhealthy landscape policy recommendations on land use change and infectious disease emerging. Environmental Health Prospect, 112, 1092-1098. https://doi.org/10.1289/ehp.6877

Rodríguez-Morales, A. J., MacGregor, K., Kanagarajah, S., Patel, D., \& Schlagenhauf, P. (2020). Going Global Travel and the 2019 Novel Coronavirus. Travel Medicine and Infectious Disease, 33(January), 101578. https://doi.org/10.1016/j.tmaid.2020.101578

Roy, M. K., Chowdhury, N. A., \& Rahman, M. (Eds.) (2007). Good Governance in Rural Development. In Proceedings of an International Training Course. Comilla: Bangladesh Rural Development Academy.

Satterthwaite, D., Sverdlik, A., \& Brown, D. (2019). Revealing and Responding to Multiple Health Risks in Informal Settlements in Sub-Saharan African Cities. Journal of Urban Health, 96(1), 112-122. https://doi.org/10.1007/s11524-018-0264-4

Schanberg, S. (1971). South Asia: The Approach of Tragedy. The New York Times, 17 June 1971.

Seagle, E. E., Dam, A. J., Shah, P. P., Webster, J. L., Barrett, D. H., ... Marano, N. N. (2020). Research Ethics and Refugee Health: A Review of Reported Considerations and Applications in Published Refugee Health Literature, 2015-2018. Conflict \& Health, 14(1), 39. https://doi.org/10.1186/s13031-020-00283-z

Shaw, R., Kim, Y.-K., \& Hua, J. L. (2020). Governance, Technology and Citizen Behavior in Pandemic: Lessons from COVID-19 in East Asia. Progress in Disaster Science, 6, 100090. https://doi.org/10.1016/j.pdisas.2020.100090

Stone, D. (2018). Refugees Then and Now: Memory, History and Politics in the Long Twentieth Century: An Introduction. Patterns of Prejudice. Routledge. https://doi.org/10.1080/0031322X.2018.1433004

Stein, B. N. (1983). The Commitment to Refugee Resettlement. The Annals of the American Academy of Political and Social Science, 467.1, 187-201. https://doi.org/10.1177/0002716283467001014

Swanson, D., Pintér, L., Bregha, F., Volkery, A., \& Jacob, K. (2004). National Strategies for Sustainable Development: Challenges, Approaches and Innovations in Strategic and Co-Ordinated Action. Manitoba, 
Eschborn, Bonn: The International Institute for Sustainable Development and Deutsche Gesellschaft für Technische Zusammenarbeit (GTZ) GmbH Published by the International Institute for Sustainable Development and Deutsche Gesellschaft für Technische Zusammenarbeit (GTZ) G.

Toole, M. J., \& Waldman, R. J. (1997). The public health aspects of complex emergencies and refugee situations. Annual review of public health, 18(1), 283-312. https://doi.org/10.1146/annurev.publhealth.18.1.283

Truelove, S., Abrahim, O., Altare, C., Lauer, S. A., Grantz, K. H., Azman, A. S., \& Spiegel, P. (2020). The potential impact of COVID-19 in refugee camps in Bangladesh and beyond: a modeling study. PLoS medicine, 17(6), e1003144. https://doi.org/10.1371/journal.pmed.1003144

UNEP. (2007). Biodiversity and Human Well-Being: Global Environmental Outlook-4 Fact Sheet 7. Nairobi, Kenya.

UNHCR-WFP. (2019). Joint Assessment Mission (JAM) Report 2019. Retrieved from https://data2.unhcr.org/en/documents/download/72273

UNHCR. (2000a). Rupture in South Asia. The State of The World's Refugees 2000: Fifty Years of Humanitarian Action, 59-79.

UNHCR. (2000b). The State of The World's Refugees 2000: Fifty Years of Humanitarian Action. Geneva. Retrieved from https://www.unhcr.org/publications/sowr/4a4c754a9/state-worlds-refugees-2000-fifty-yearshumanitarian-action.html

UNHCR. (2019). Rohingya Refugee Response, 1-2. Retrieved from http://data2.unhcr.org/en/situations/myanmar_refugees

UNHCR. (2020a). Financials | Global Focus. Financials. 2020. Retrieved from https://reporting.unhcr.org/financial\#_ga=2.235807873.1446072355.1592317966-827901760.1575623514

UNHCR. (2020b). Figures at a Glance. Retrieved from https://www.unhcr.org/figures-at-a-glance.html

Venkatesan, G., Balamurugan, V., Gandhale, P. N., Singh, R. K., \& Bhanuprakash, V. (2010). Viral zoonosis: a comprehensive review. Asian Journal of Animal and Veterinary Advances, 5(2), 77-92.

Vieira, C. M., Franco, O. H., Restrepo, C. G., \& Abel, T. (2020). COVID-19: The Forgotten Priorities of the Pandemic. Maturitas, 136(April), 38-41. https://doi.org/10.1016/j.maturitas.2020.04.004

Vos, R., Martin, W., \& Laborde, M. (2020). How Much Will Global Poverty Increase Because of COVID-19? International Food Policy Research Institute. Retrieved from https://www.ifpri.org/blog/how-much-will-global-poverty-increase-because-covid-19

Whiting, K. (2020). Coronavirus Isn't an Outlier, It's Part of Our Interconnected Viral Age. World Economic Forum. Retrieved June 19, 2020, from https://www.weforum.org/agenda/2020/03/coronavirus-globalepidemics-health-pandemic-covid-19/

Wiesmann, D., Weingärtner, L., \& Schöninger, I. (2006). The Challenge of Hunger: Global Hunger Index: Facts, Determinants, and Trends. Bonn and Washington, DC: Welthungerhilfe and International Food Policy Research Institute.

Wilson, R. A., \& Brown, R. D. (Eds.) (2009). Humanitarianism and Suffering: The Mobilization of Empathy. Cambridge, UK: Cambridge University Press.

Wilke, I. G., \& Haas, L. (1999). Emergence of "new" viral zoonoses. DTW. Deutsche Tierarztliche Wochenschrift, 106(8), 332-338.

World Economic Forum. (2020). The Global Risks Report 2020. Retrieved from https://es.weforum.org/reports/the-global-risks-report-2020

\section{Copyrights}

Copyright for this article is retained by the author(s), with first publication rights granted to the journal.

This is an open-access article distributed under the terms and conditions of the Creative Commons Attribution license (http://creativecommons.org/licenses/by/4.0/). 